\title{
The Output Hypothesis and its influence in the second language learning/teaching: An interview with Merrill Swain
}

\author{
A Hipótese da Produção e sua influência no ensino/aprendizagem de \\ segunda língua: Uma entrevista com Merrill Swain
}

Entrevistador: Antonia de Jesus Sales ${ }^{1}$

Submetido em 14 de maio e aprovado em 26 de junho de 2020.

\begin{abstract}
This paper presents an interview with Merrill Swain, a Canadian researcher who proposed the Output Hypothesis, a way to understand the relevance of producing (by speaking/writing) the foreign language during its learning. According to Output Hypothesis, the learner may notice gaps while, test cognitive hypothesis and think in a metalinguistic way while producing the foreign language. This hypothesis influenced plenty of research in the second language learning/teaching field around the world, considering Brazil as well.
\end{abstract}

Keywords: Output Hypothesis. Language Learning/Teaching. Canadian Research.

Resumo: Apresentamos aqui uma entrevista com Merrill Swain, uma pesquisadora canadense que propôs a Hipótese da Produção, uma forma de compreender a relevância da produção de língua (ao falar ou escrever) durante sua aprendizagem. Segundo a Hipótese da Produção, o aprendiz poderá perceber lacunas enquanto testa hipóteses cognitivas e refletir de forma metalinguística enquanto produz a língua estrangeira. Esta hipótese influenciou diversas pesquisas no campo da aprendizagem/ensino de segunda língua ao redor do mundo, considerando o Brasil também.

Palavras-chave: Hipótese da Produção. Aprendizagem/Ensino de Língua. Pesquisa Canadens. 
Merrill Swain is an emerita professor in the second language education field at the Ontario Institute for Studies in Education (OISE) - at the University of Toronto. Professor Swain developed the Output Hypothesis based in the Sociocultural or Social Interactional Theory, by Vygotsky. Thus, Swain considers that learning new issues is not enough so that the learning occurs and for having the real learning happening it is necessary that the student gets the opportunity to produce, to test, and to think over new things. The Output Hypothesis encompasses the oral and written production (output).

Another relevant point is that this hypothesis doesn't deny the role of input in the second language acquisition. Swain considers that even considering the importance of the input in the second language acquisition, this is not enough so that learners develop in a full way the proficiency in a second language learning process.

According to Swain, the Output Hypothesis, then, has three functions occurring interchangeably: the noticing function, the hypothesis testing and the metalinguistic function. So, while producing in the second language, a learner may notice what he/she knows fully or partially. He may also test what he thinks is the right way of speaking or writing in the foreign language and doing so, he may engage in a metalinguistic action. In other words, Swain points out that when producing language (by speaking/writing) the student may notice gaps in his interlanguage and while trying to produce the foreign language, automatically he will test what he knows about it and reflect over it, resulting in real learning.

The Output Hypothesis has influenced new topics in second language research in many places. It has some influence in Brazil research as well. In order to discuss the relevance of this hypothesis in the second language field, we present below an interview with professor Swain. After that, we present some relevant papers produced by professor Swain: 


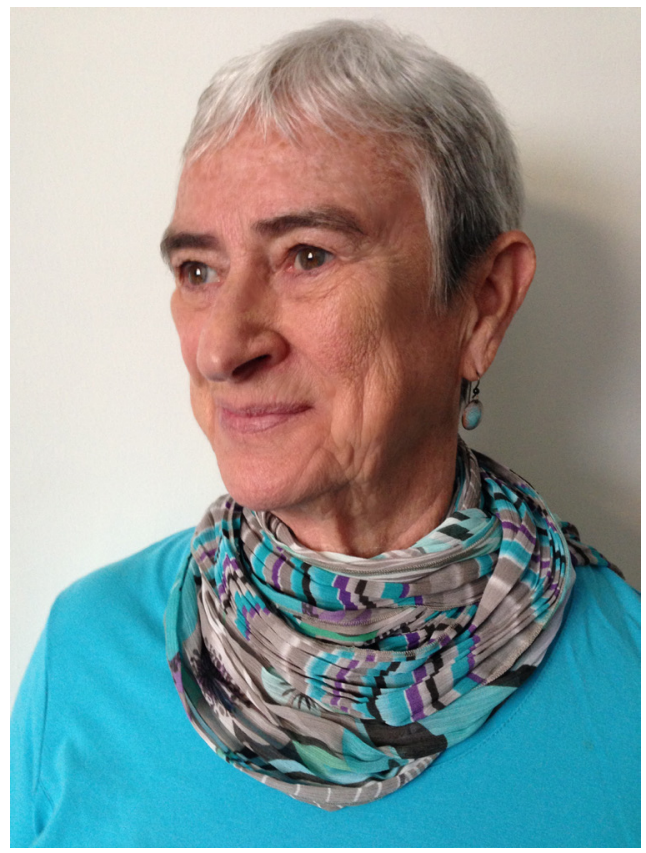

Interviewer - First, I want to know how you have developed the Output Hypothesis. I know it started with your research on bilingual French immersion programs in Canada, right? Did you start observing the classrooms or analyzing the methods first?

MS - We spent a lot of time in immersion classrooms. We were around when the first French immersion programs in Ontario began. We were asked to go in and evaluate them. We spent a lot of time talking to teachers and observing classes.

\section{Interviewer - And I suppose it was a hard work.}

MS - No, it was fascinating. It was such a new thing, it was a novel idea, the teachers were very committed. It was an exciting time. Today immersion programs have been around so many years they are considered as just a regular program.

Interviewer - And so those students didn`t speak French. Their mother tongue was English, right? 
MS - In the initial programs, the students' first language was English. But, as time went on, people from other language backgrounds became interested in having their children in the program. These parents, too, saw it as being an advantage to send their children to French immersion programs.

\section{Interviewer - And then it was like immersion schools, right?}

MS - No, not the whole school usually. Usually only a section of a school would be French immersion.

Interviewer - When I was reading your articles, as for second language acquisition, I understood that you see output and input as complementary to each other. Am I right?

MS - Yes. Krashen doesn 't think so. Krashen sees input as all that is needed for second language acquisition. We know from our research and other research that if all you do is provide students with input, and students don't get a chance to use the language, there are a lot of things that the students don`t learn. So Krashen is wrong.

\section{Interviewer-How do you like translation tasks for second language acquisition?}

MS - In the immersion programs there was a rule that teachers were supposed to follow which was that they were not to use the first language in a classroom. The teacher wasn `t supposed to use it and the students weren `t supposed to use it. But the reality was that, of course, teachers and students used it. From a sociocultural theoretical point of view, the first language is a resource. And after all, if you, for example, are forbidden to use your first language, then you will use it in your head. I think that what learners do is more that just translate; that is, the L1 is, initially at least, a mediating cognitive tool. Students make use of the resources they have which includes their first language, in order to help/support/scaffold themselves in order to learn the second language. Does direct translation play a role? I'm sure it does, but that is not the only function of using the L1. So, I think if you are going to use translation texts, then you have to think carefully about what it is that you want the students to learn from them and what the texts could be. 
Interviewer - In one of your articles, you say that "language is both process and product". When you say "language is both process and product", how do you see the translation tasks fitting into the output hypothesis?

MS - Translation tasks involve both process and product. From a learning and teaching point of view, it really matters to be able to see what the process is, what students are doing when they translate, what they are going through, how they end up with a particular product. That is why the concept of languaging is so important as languaging is about the process, It is about how to get there. Output is the product.

Interviewer - When talking about translation texts, I suppose teachers should work with different text genres. Do you think teachers should bear in mind the functions of the activity, I mean, all the processes (noticing, hypothesis testing, reflecting) as stipulated by the Output Hypothesis?

MS - Well, first, one has to show through research that translation texts in fact lead students to notice, hypothesis test and/or reflect. This is an interesting empirical question. For example, you would need to try out translation tasks in a classroom context to see if they lead to students making use of these processes.

Interviewer - When I was researching the Output Hypothesis use in Brazilian research, I found it related to a number of areas, such as the following: Education, Applied Linguistics, Linguistic Studies. What do you think of this inter-disciplinarity among the areas and the Hypothesis you developed?

MS - If you are talking about learning, then the Output Hypothesis is relevant to all learning. The process of reflecting with others or with oneself (languaging) is an important process whether you are studying Biology, Computer Sciences, Mathematics, Applied Linguistics. What we are doing right now is languaging. That's what we are doing.

Interviewer - I would like to talk about "languaging". Have you created this term? I read that Lado has discussed this term in the 80 's. Can you please explain to me the meaning of it?

MS - Lado talked about languaging in the 80 `s but he didn`t mean the same thing 
as I do. Here is basically what happened: every year I used to teach a course called sociocultural theory and second language learning and every year I used to say to the students: You know, there is this process and I don't know what to call it. So, the first thing we called it was verbalization and verbalizing, but the problem with that is that everyone thought it referred only to oral language (speaking). I needed something more general than just verbalizing. Then, one day in class, maybe I suggested the term, maybe a student did --you never know when there is a good dynamic in a class where an idea really comes from. We all thought languaging was the term I had been searching for. That evening after class, I googled it and there were a few people (e.g. Lado) who had used the term, but they didn't mean the same thing.

Interviewer - When you talk about Languaging, you mean other skills as well, right?

MS - Yes, I mean speaking and writing. Sometimes, when we are speaking and writing, we are languaging. Both spoken and written language mediates our thinking.

Interviewer - Registering and listening to what students are telling at the moment of their production (output) seems to be essential. In most of the articles I have read, you work with verbal protocols. Do you think it is still the best way to observe the cognitive processes involved in this specific case of second language learning?

MS - Yes. But what we did is not the same thing as "thinking aloud". From an information processing perspective, thinking aloud does NOT in any way affect what is in the head. All you do is think aloud: you are just taking some idea and you are using language to get it out. But the concept of languaging implies that one doesn't know what the idea is before you say it. Saying it is the cognitive process of mediating thought. Languaging is an effortful process that we need to use when engaging in a cognitively complex task, like translation.

Interviewer - Do you think, in Canada, the training of language teachers is sufficient to those who want to work with second language teaching?

MS - I don't think I can answer that. The teachers who I come in contact with are 
people like yourself. Students who come to OISE to enroll in an MA or a Ph.D. program are really interested, they're really eager to know what the newest ideas are. So, of course I think what they do is good. But if I were to walk into a school, any school in Toronto, and observe their teaching of French, I have no idea what I would see. Like I said, I can`t answer your question.

Interviewer - How do you evaluate the process in your articles, then? I mean, how did you collect the data?

MS - After students complete a task in which they engage in collaborative dialogue, and that we recorded, we've gone back to the tape and listened to what students have said. Where we had questions, we played the recording to the pair of students and asked them what they were thinking at the time. Another way it can be done is just record and then the students come back and play the tape recording. As the researcher and students listen, either stops the tape recorder whenever one hears something that is not comprehensible or that needs explaining. This process is known as stimulated recalls where what the students have said acts as the stimulus for reflection. I think stimulated recalls are a great tool for collection data. They provide such rich data.

In one of our studies, we asked students in pairs to write a story. After they wrote the story, we reformulated the text. Then we gave back to them the reformulated text so that they could see where we had made changes and we asked them whether they accepted the change or not. When they didn't accept the change, we asked them to say why not. And then, after that, they were asked to write the story again, but this time they were to write it alone. Up until then, students were engaged in noticing, hypothesistesting and reflecting, and at the end of that time, we wanted to see what they had learned, and if what they learned (what they produced at the final writing) was reflected in what they had said (= languaging).

And the reason we conducted the study in the way that we did was to have the students write their own pre-test and post-test. If you think about it, most SLA studies have a pre- and post-test, both of which are generated by the researcher. The researcher decides what is going to be the pre-test. For example, say I want to teach the past tense, I 
will give the students a number of test items to see what they know about the past tense. Then I do some sort of intervention and then I give them another test, the same test or a similar test, to see what they have learned about the past tense from my intervention.. That is what normally happens and what we did was completely different, because what we noticed was that students were learning aspects of the target language, but it wasn ` measured by the difference between the pre- and post-tests. Why? Usually because what was being measured wasn't what the students focused on; it didn't relate to what they were interested in talking about, that is, what they were ready to learn. So, we decided that the only way we could discover what was learned while doing the task was to have the story the students first wrote as the pre-test (i.e., each pair wrote their own pre-test), and the story they wrote at the end, the post-test. It meant that every pair wrote different things (as pre- and post-tests). What students ended up writing at the end was in large part related to all the talk between the pre- and post-test which we could trace in their languaging. For example, a pair of students might say they didn't agree with a particular correction, and then they languaged about it, deciding what was the correct form. By looking at the post-test, we could see whether or not they actually made the relevant change as a result of this process. So, it is a very different conceptualizaton of what a preand post-test should consist of. What you are doing is capturing the actual learning that you want to capture, instead of capturing the learning that you think should be going on, but maybe isn't at all.

In my view, this means that most of the results that you read about in SLA studies are a conservative estimate of what has been learned. Sure, you can observe what the students learned about the past tense, maybe. But what you don't capture are all the other things that students learn by talking and collaborating with each other. So I think that probably the results that we read in the SLA research literature are very conservative. They under-represent how much learning actually happens in collaborative situations.

Interviewer - Another question I have is about "agency". What does "agency" mean, exactly?

MS - "Agency" is represented in the fact that you actually found your way from 
Brazil to here, chez moi! "Agency" is the individual choosing to do something or not. So, if you take an EFL classroom context, there may be students who dislike their teacher, they don't want to learn English, all these sorts of things. "Agency" would be resisting learning English, demonstrated in any number of ways including just sitting around and doing nothing in class. "Agency" takes the learner into account, it takes the individual's goals into account, as well as the resources (the mediational tools) the learner has to enact his or her agency.

Again, if you think about a lot of SLA studies, the researchers give a pre-test, they do an intervention and they give a post-test. But they rarely talk to the students, they don't know what the students' interests are. They don't know why students would decide to pay attention, or not, they know almost nothing about the students. One of the things we found from the stimulated recalls and interviews is how much agency the students have. They said: "You know, I know that was an adult that corrected us and I know that was somebody who knows English, but I don't agree with what they said. I don't agree because that's not what my other teacher told us, so I'm going to stick with my decision". That student is exercising her "agency". Some people would call it will power, but it is not just will power, it's planning, it's having goals. Agency accounts for what people learn. Maybe your brother is a good example; as you said he doesn't want to learn English, he doesn't want to learn about computers. But it doesn't mean that he doesn't have "agency". He has agency to resist learning English and about computers. He has chosen to do something else instead. Because of an individual's particular history, because of the context that is available at the time, they choose to do one thing rather than another.

Interviewer - What attracted you to second language learning and teaching? What made you interested in this field?

MS - Fundamentally, my parents had a positive attitude towards learning French but I had no access to French in school in Vancouver, there was no possibility of studying it. The first time I was taught French formally was in Toronto in grade 9. In grade 9, my grades in French were very good, they were like 100 percent. And then the next year, they started going down, and then the next year they got worse, and then the next year they got even worse. And it was because I was taught grammar and nothing but grammar. The 
idea that language had a purpose, that language was there to make meaning, that language was there to introduce people to new cultures, these were not part of what we were taught. And furthermore, our teachers would teach us French in English, so I learned nothing. I was very turned off learning French. But then I went to university and there was a requirement to take one year of French in order to graduate. So I took my required French course. I was taught by a woman from France and she was fantastic! She was lively, she was an amazing teacher and she never used a word in English in class. That teacher was instrumental in interesting me again in learning French.

Then I went to Graduate School and I had to figure out what I was going to do for my $\mathrm{PhD}$. Research. It occurred to me that I could research how young children learn two languages simultaneously in Quebec city so that I could learn French while collecting my data. I don't know which came first: the fact that I wanted to go and live in Quebec to learn French or whether I wanted to conduct research about simultaneous bilingual development and then decided to go to Quebec. I was living in Quebec city when the first immersion program started in St. Lambert (near Montreal). I used to go from Quebec city to Montreal to talk to Drs. Lambert, Tucker and McNamara at McGill University who were evaluating the St Lambert French immersion program and conducting research concerned with bilingualism. So that's how I got to know about the initial French immersion program which evaluations demonstrated were highly successful, so successful that similar programs were initiated elsewhere, for example, Ottawa and Toronto. The federal government and the provincial government, for different reasons, wanted to fund evaluations of these programs. Dr. H.H. (David) Stern was asked to conduct these evaluations and also help with curriculum development.

Dr. Stern advertised across Canada to hire somebody to evaluate the Toronto and Ottawa French immersion programs. He found out that I existed because of my contacts with the McGill group. I was offered the position. But I said "No, I can't take the job, because I have to finish my Ph.D first." He asked when I was going to finish it. And I said, it would be about 6 months. And he said "Fine, so in 6 months you start". It was amazing, I was so lucky!" So, I moved to Toronto and I was in charge of the project to evaluate these immersion programs. Like I said, to this day, observing in the schools, seeing what 
was going on, was the best job in the world! And the results from the evaluations were so positive. The children were learning a lot more French than in the 20 minutes a day program, they were learning content material, they were engaged learners. I am totally convinced that if I had had the opportunity of attending a French immersion program, I would be fluently bilingual now.

\section{References}

Johnson, R.K., \& Swain, M. (Eds.). Immersion education: International perspectives. Cambridge: Cambridge University Press, 1997.

Swain, M., \& Watanabe, Y. Collaborative dialogue as a source of learning. In C. Chapelle (Ed.), The encyclopedia of applied linguistics. Oxford, UK: Wiley Blackwell, 2013.

Swain, M., Kinnear, P., \& Steinman, L. Sociocultural theory in second language acquisition: An introduction through narratives. Bristol, UK: Multilingual Matters, (2011; Second Edition 2015).

Swain, M. "Talking it Through: Languaging as a source of second language learning. In R. Batstone (Ed.), Sociocognitive perspectives on second language learning and use. Oxford: Oxford University Press, (pp. 112-129), 2010.

Swain, M. Languaging, agency and collaboration in advanced second language learning. In H. Byrnes, (Ed.), Advanced language learning: The contribution of Halliday and Vygotsky, London, UK: Continuum, (pp. 95-108), 2006.

Swain, M. The output hypothesis: Theory and research. In E. Hinkel (Ed.), Handbook of research in second language teaching and learning. Mahwah, NJ: Lawrence Erlbaum, 2005, (pp. 471-484).

Swain, M., \& Lapkin, S. Focus on form through collaborative dialogue: Exploring task effects. In M. Bygate, P. Skehan \& M. Swain (Eds.), Researching pedagogic tasks: Second language learning, teaching and testing. London, UK: Longman, (pp. 99-118), 2001.

Swain,M. The output hypothesis and beyond: Mediating acquisition through collaborative dialogue. In J. P. Lantolf (Ed.), Sociocultural theory and second language learning. Oxford: Oxford University Press, (pp. 97-114), 2000.

Swain, M. French immersion in Canada. In J. Cummins (Ed.), Bilingual education, Volume 5 of The encyclopedia of language and education. Dordrecht, Holland: Kluwer Academic Press, (pp. 261 269), 1997.

Swain, M. Three functions of output in second language learning. In G. Cook \& B. Seidlhofer (Eds.), Principle and practice in applied linguistics: Studies in honour of H. G. Widdowson. Oxford: Oxford University Press, (pp.125 144), 1995.

Swain, M., \& Lapkin, S. A Vygotskian perspective on immersion education: The L1/ L2 debate. Journal of Immersion and Content Based Language Education, 1, (pp. 101- 
129), 2013.

Swain, M. The inseparability of cognition and emotion in second language learning. Language Teaching, 46, (pp. 195-207), 2013

Swain, M., Lapkin, S., Knouzi, I., Suzuki, W., \& Brooks, L. Languaging: University students learn the grammatical concept of voice in French. Modern Language Journal, 93, (5-29), 2009.

Swain, M., \& Deters, P. "New" mainstream SLA theory: Expanded and enriched. The Modern Language Journal, 91, Focus Issue 1, (pp. 820-836), 2007.

Swain, M., \& Lapkin, S. The evolving socio-political context of immersion education in Canada: Some implications for program development. International Journal of Applied Linguistics, 15 (2) (pp. 169-186), 2005.

Swain, M., Brooks, L., and Tocalli-Beller, A. Peer-peer dialogue as a means of second language learning. Annual Review of Applied Linguistics, 22, Cambridge: Cambridge University Press, (pp. 171-185), 2002.

Swain, M., \& Lapkin, S. Talking it through: Two French immersion learners' response to reformulation. International Journal of Educational Research (Special issue on the role of interaction in instructed language learning) 37: (pp. 285-304), 2002.

Swain, M. \& Lapkin, S. Task-based second language learning: The uses of the first language. Language Teaching Research 4: (pp. 253-276), 2000.

Swain, M. French immersion research in Canada: Recent contributions to SLA and applied linguistics. Annual Review of Applied Linguistics, 20: (pp. 199-212). Cambridge: Cambridge University Press, 2000.

Swain, M. Integrating language and content in immersion classrooms: Research perspectives. Canadian Modern Language Review, 53: (pp. 529-548), 1996.

Swain, M. Manipulating and complementing content teaching to maximize second language learning. TESL Canada Journal, 6: (pp. 68-83), 1988.

Swain, M. Time and timing in bilingual education. Language Learning 31: (pp. 1-15), 1981.

\section{Note}

1 Professor at Federal Institute of Education, Science and Technology of Ceará - IFCE (Tauá Campus). Taking a PhD at the Postgraduate Program in Translation Studies - (PGET) at Federal University of Santa Catarina (UFSC). 